\title{
Land Tenure Without Rights by the Community Case Study on Supreme Court Decision Number 1638K / Pdt / 2010
}

\author{
Aril Hidayatullah ${ }^{1} \quad \mathrm{Arba}^{2} \quad$ Sahnan $^{2}$ \\ 1.Graduate Program Student in Notary, Faculty of Law, Mataram University, Indonesia \\ 2.Lecturer of Faculty of Law, Mataram University, Indonesia
}

\begin{abstract}
This study aims to determine and analyze the Legal Position / Land Status of Disputed Objects in the Supreme Court's Decision Number 1638K / Pdt / 2010 and whether the Judge's Consideration in the Supreme Court's Decision Number 1638K / Pdt / 2010 is in accordance / not with Justice and Legal Certainty. The theory used in this research is the theory of legal certainty, the theory of legal protection, the theory of justice, and the theory of expediency. The method of approach used in this study is the legislative approach, the concept approach, and the case approach. The results of this study indicate that: the land of disputed objects in the Supreme Court's Decision Number: 1638K / Pdt / 2010 is Amaq Dinah's land based on Garuda Pipil Number: 115 Persil Number: 9 of 1957 , which has been seized by the DJM and the acquisition of Ratna Sari Dewi is not based on law , because the Certificate of Ownership No. 1507, area of 4,024 m2 Situation (GS) was issued on August 11, 1988 Number: 1268/1988 in the name of Ratna Sari Dewi and Certificate of Ownership Number: 1508, area of 1,837 m2 Situation Image (GS) ) on August 11, 1988 Number: 1267/1988 on behalf of Ratna Sari Dewi rather than the sale and purchase between Ratna Sari Dewi as the buyer and DJM Sambara through his attorney named Matius Nika Tandipare as the attorney of DJ Sambara based on the Deed of Sale and Purchase Number: 76 / AU / CA / VII / 1996 and 90 / AU / CA / VIII / 1996 dated July 26, 1996.
\end{abstract}

Keywords: Land Tenure

DOI: $10.7176 / \mathrm{JLPG} / 98-09$

Publication date:June 30th 2020

\section{Introduction}

Legal Issues for Land Tenure without Rights by the Community Case Study of the Decision of the Supreme Court Number 1638K / Pdt / 2010 is very important to be investigated. Regarding the control and ownership of land rights has always been a hot issue to be discussed, because it is related to rights and obligations. Justice in the possession / control of agrarian / land resources as the biggest people's livelihood resources that must be managed properly for community empowerment.

About the Dispute Object:

1. Certificate of Ownership Number: 1507, area 4,024 m2 Situation Image (GS). August 11, 1988 Number: $128 / 1988$ in the name of Ratna Sari Dewi.

2. Certificate of Ownership Number: 1508, area 1,837 m2 Situation Figure (GS). August 11, 1988 Number: $1267 / 1988$ in the name of Ratna Sari Dewi.

The disputed land is Alm Munirah alias Amaq Dinah where the land was sold by his son, Alm Musdah to DJM Sambara in 1983, which was sold by Alm Musdah at only $800 \mathrm{~m} 2$ and at the time of the sale Alm Musdah was pressured and coerced by DJM Sambara who is a TNI Officer, the acquisition was not obtained in Good faith and in reality from the sale and purchase of the Certificate of Ownership (SHM) was issued in 1994 with the Decree of the Regional Office of BPN NTB on February 2, 1994 No. SK.520.1/737/1/790/62/94: SHM 507/1994 and No. SK.520.1 / 737/1/789/62/94: SHM 508/1994 and has been sold to Hj. Ratna Sari Dewi as the buyer and DJM Sambara through his attorney named Matius Nika Tandipare as the attorney of DJM Sambara based on the Sale and Purchase Deed Number: 76 / AU / CA / VII / 1996 and 90 / AU / CA / VIII / 1996 dated July 26, 1996. Whereas the obscurity of the object of sale and purchase of Ratna Sari Dewi as the buyer and DJM of Sambara through his attorney named Matius Nika Tandipare as the authority of DJM Sambara based on the Sale and Purchase Deed Number: 76 / AU / CA / VII / 1996 and 90 / AU / CA / VIII / 1996 dated July 26, 1996. Since the first came out Certificate of Ownership Number: 1507, area 4,024 m2 Situation Pictures (GS) dated August 11, 1988 Number: 1268/1988 on behalf of Ratna Sari Dewi and Certificate of Ownership Number: 1508, area 1,837 m2 Image Situation (GS) on 11 August 1988 Number: 1267/1988 on behalf of Ratna Sari Dewi.

\section{Research methods}

This legal research is a normative legal research that examines jurisprudence namely the Supreme Court Decision of the Republic of Indonesia Number: 1638 K / Pdt / 2010 which contradicts the Basic Regulations namely the Body of the 1945 Constitution namely Article 28D Paragraph (1) of the 1945 Constitution, Laws Number 5 of 
1960 concerning Basic Regulations on Agrarian Principles, Government Regulation Number 24 of 1997 concerning Land Registration and Regulation of the Head of BPN Number 3 of 2011 concerning Management of Assessment and Handling of Land Cases. This type of research in this study is research that wants to examine the synchronization of laws and regulations. The approach used in this study is 1) The statute approach, which relates to the problem being studied by examining the relevant laws and regulations with the legal issues being faced. 2) Concept approach (conceptual approach), which examines legal concepts related to research problems. 3) Case Approach (Case Approach), This approach is carried out by examining cases related to the legal issues at hand. The cases examined are cases that have obtained a court decision of permanent legal force. ${ }^{1}$

The technique used in the collection of legal materials is to study and analyze primary legal materials, secondary legal materials and tertiary legal materials, namely using documentary studies. Documentary studies are studies that examine various documents, both related to laws and regulations existing documents.

\section{Results and discussion}

\subsection{STATUS / STATUS OF LAND IN THE DECISION OF THE SUPREME COURT NUMBER 1638K / PDT / 2010.}

3.1.1 Legal Recognition and Protection of Community Land Rights in RT. 08 Pondok Perasi Environment in the Supreme Court Decision Number: 1638K / Pdt / 2010

Recognition and legal protection in the use of natural resources is the right of every citizen that must be guaranteed by the authorized government, the government is prohibited from acting arbitrarily against the existence of people who have inhabited a land since hereditary from their ancestors. Recognition and protection are also contained in the prohibition of the practice of fraud, confiscation and prohibition of all actions that harm property including the property of others. ${ }^{2}$

Speaking of protection, we are talking about the actions of the authorities towards the people in order to guarantee the security and order of the community in order to provide protection and provide security to the community in enjoying all rights given by law, so as to provide peace in the community.According to Satjipto Rahadrjo that:

"Legal protection is providing protection for human rights that are harmed by others and the protection is given to the public so that they can enjoy all the rights granted by the law or in other words legal protection is a variety of legal efforts that must be given by law enforcement officials to provide a sense of security, both mind and physical from interference and various threats from any party. " 3

According to Arba:

"The conception of the word protection in relation to legal protection is the regulation of certain things in order to get a safe place or regulation of something by law so that their rights and obligations are protected by law. Therefore, every act carried out by legal subjects is truly the provisions of the applicable law. get legal protection." 4

Whereas when speaking in the context of land law, legal protection of land rights for the community is the right of every citizen as mandated by Article 28D Paragraph 1 of the 1945 Constitution which states that "Every person has the right to recognition, guarantees, protection, and certainty of legal justice as well as equal treatment before the law"

Land has a very important position in the life of the nation and state, because land can be used for development, both infrastructure such as roads, irrigation, telecommunications and in agriculture, animal husbandry, mining, housing, even today the land has become a commodity that has high economic value.$^{5}$

Speaking of Human Rights or Human Rights, According to Law Number 39 of 1999 Concerning Human Rights, Human Rights are: "Human Rights are a set of rights inherent in the nature and existence of human beings as God's creatures and are His gifts that must be respected, upheld and protected by the state, law and government, and everyone for the sake of respect and protection of human dignity and dignity. "

The basic rights inherent in human beings are natural, universal, and eternal as a gift from God Almighty, including the right to life, the right to family, the right to develop themselves, the right of justice, the right of communication, the right of communication, the right of security, and the right of welfare, which must therefore not be ignored or seized by anyone.

Required DJM Sambara who is a TNI Officer who took the necessary actions for Alm Musdah, because DJM Sambara when buying land from Alm Musdah who was the son of Alm Munirah aka Amaq Dinah by force, he provided a coercion for Alm Musdah in order to be able to buy the given goods by Alm Munirah Alias Amaq

\footnotetext{
${ }^{1}$ Amiruddin \& Zainal Asikin, Pengantar Metode Penelitian Hukum, Ed. Revisi. Cet. 10, Rajawali Pers, Jakarta, 2018 , halaman 165.

${ }^{2}$ Achamd Ali, Perlindungan Hak Asasi Manusia Dibidang Kepemilikan Tanah, Komisi Nasional Hak Asasi Manusia, Jakarta, 2005, halaman $14-15$.

${ }^{3}$ Satjipto Rahardjo, Penyelenggaraan Keadilan Dalam Masyarakat Yang Sedang Berubah, Jurnal Masalah Hukum , 1993.

${ }^{4}$ Arba, Hukum Tata Ruang dan Tata Guna Tanah (Prinsip-prinsip hukum perencanaan penataan ruang dan penatagunaan tanah), Pustaka Bangsa, Mataram, 2014, halaman. 228.

${ }^{5}$ Salim HS, Teknik Pembuatan Akta Pejabat Pembuat Akta Tanah, Rajawali Pers, Jakarta, 2016, halaman 1.
} 
Dinah who is the father of Alm Musdah. And at the time of the sale and purchase in 1983, DJM Sambara also asked for approval from Usman and Sakmah who were brothers of Alm Musdah in order to be able to buy and buy it, agreed to be supported by DJM Sambara also by force.

In Article 1323 of the Civil Code:

"Coercion carried out against the person making the agreement, the cancellation of the agreed agreement, also if coercion was carried out by a third party who is not interested in the agreement made." If we refer to Article 1323 of the Civil Code mentioned above, it is clear that coercion carried out against the person making an agreement results in the cancellation of the agreement concerned, also if coercion was carried out by third parties who have no interest in the agreement made. This means that the coercion undertaken by DJM Sambara to Alm Musdah that Alm Musdah sold his land resulted in the cancellation of the agreement, because Alm Musdah was under pressure, forced by DJM Sambara who was a TNI Officer to sell his land. This means that the acquisition obtained by DJM Sambara through buying and selling with Alm Musdah was not obtained in Good Faith, because DJM Sambara obtained the land in an improper manner, it is not appropriate before the law by forcing the Alm Musdah to sell the land to him. In this case Munirah aka Amaq Dinah, whose land has been sold by her son, is musdah but was sold because it was under duress by DJM Sambara who was a TNI Officer and now the land is occupied by his son, Maemunah along with other residents, even DJM Sambara and Ratna Sari Dewi who have been buying land from DJM Sambar also never occupied the land at all. Therefore, Munirah Alias Amaq Dinah whose land has been confiscated and is now occupied by her heirs, namely Maemunah, must receive protection from her rights that have been harmed by others and the protection is given to the community so that they can enjoy all the rights granted by law or in other words legal protection is a variety of legal efforts that must be given by law enforcement officials to provide a sense of security, both mind and physical from interference and various threats from any party.

3.1.2 Utilization of Land by the Community in RT 08 Pondok Perasi Environment in the Supreme Court Decision Number 1638K / Pdt / 2010

Speaking of expediency means talking about the purpose of law, the purpose of law is to provide the greatest benefit and happiness to as many citizens as possible.

If we talk about the use of land, then we are referring to Article 33 Paragraph 3 of the 1945 Constitution which reads: "The earth and water and the natural resources contained therein are controlled by the state and are used for the greatest prosperity of the people."

Article 33 Paragraph (3) of the Constitution of the Republic of Indonesia with the statement of the "founding fouther" of the Unitary State of our Republic of Indonesia and its constitution: Earth and Water and Natural Resources contained therein shall be controlled by the State and used for the greatest prosperity of the people. ${ }^{1}$

The land of water and the natural resources contained therein are used for the greatest prosperity of the people, affirming the people's sovereignty and the position of the people (substance). ${ }^{2}$

Thus with respect to land rights or land use, justice and protection of personal interests must be achieved to achieve the greatest happiness for as many people as possible. In this case the indigenous people who used the land since before Indonesian independence was Munirah Alias Amaq Dinah who had an eagle pipam which had been forcibly taken away by DJM Sambara, which is now controlled and used by his grandchildren, Maemunah along with other residents.

In this case Munirah aka Amaq Dinah, whose land has been sold by her son, is musdah but was sold because it was under duress by DJM Sambara who was a TNI Officer and now the land is occupied by his son, Maemunah along with other residents, even DJM Sambara and Ratna Sari Dewi who have been buying land from DJM Sambar even never occupy the land at all, therefore Munirah Alias Amaq Dinah whose land has been confiscated and now occupied by its heirs namely Maemunah together with other residents must obtain the greatest benefit and happiness for those citizens who still occupy the land. So, the concept puts benefit as the main goal of law. Its size is as much happiness as possible for as many people as possible. Judging whether good or bad, just or not, this law is very dependent on whether the law is able to provide happiness to humans or not. Benefit is interpreted the same as happiness.

\subsection{JUDGMENT CONSIDERATIONS IN THE DECISION OF THE SUPREME COURT NUMBER 1638K / PDT / 2010 REVIEWED FROM THE JUSTICE AND LEGAL SURE.}

3.2.1 Aspects of Justice in the Consideration and Decision of the Supreme Court Number 1638K/ Pdt / 2010

John Rawls presents the concept of social justice. Social justice is: "The principle of rational wisdom that is applied to the concept of aggregate welfare (the result of gathering) groups". ${ }^{3}$

The main subject of social justice is the structure of society, or more precisely the way the main social institutions distribute fundamental rights and obligations and determine the distribution of profits from social

\footnotetext{
${ }^{1}$ Boedi Harsono, Hukum Agraria Indonesia Himpunan Peraturan-Peraturan Hukum Tanah, Cet. 19, Djambatan, Jakarta, 2008, halaman XXV.

${ }^{2}$ Anang Husni dan Itta Soraya, Antropologi Hukum, Cetakan Pertama, Mataram University Press, Mataram, 2018 , halaman 132.

${ }_{3}^{3}$ Sudikno Mertokusumo, Teori Hukum, Cetakan I, CV Mahakarya Pustaka, Yogyakarta, 2019, halaman 30-31.
} 
cooperation. $^{1}$

Furthermore, John Rawls emphasized that the program of justice for a populist dimension must pay attention to two principles of justice, namely:

"First, provide equal rights and opportunities for the most basic basic freedoms as wide as the same freedom for everyone. Second, able to re-regulate the socio-economic inequalities that occur so as to provide reciprocal benefits for everyone, both those who are from lucky or unlucky groups. "2

Thus the principle of difference requires the arrangement of the basic structure of society in such a way that the gap in the prospects of prosperity, income, and authority is for the benefit of the most disadvantaged. This means social justice must be fought for two things, which include: ${ }^{3}$

"First, make corrections and improvements to the conditions of inequality experienced by the weak by presenting empowering social, economic and political institutions. Secondly, each rule must position itself. Each of the above views differs in the focus of their study of justice. Plato views justice from benefits. Aristotle views justice from law and equality. While John Rawls views justice from social justice. "4

If we examine the concept of justice according to John Rawls it means that it refers to social justice that is in line with the fifth precepts of Pancasila namely Social Justice for All Indonesian People. Seeing the facts that the Judge's Consideration in the Supreme Court Decision Number 1638K / Pdt / 2010 does not match justice because the land which was originally the land of Alm Munirah aka Amaq Dinah where the land was sold by his son namely Alm Musdah to DJM Sambara in 1983 Alm Musdah was only sold for $800 \mathrm{~m} 2$ and at the time of the sale Alm Musdah was pressured and coerced by DJM Sambara who was a TNI Officer, his acquisition was not obtained in Good faith and in fact from the sale and purchase of the Certificate of Ownership (SHM) was issued. in 1994 with the Decree of the NTB Regional Office BPN on February 2, 1994 No. SK.520.1 / 737/1/790/62/94: SHM 507/1994 and No. SK.520.1/737/1/789/62/94: SHM 508/1994 and has been sold to Hj. Ratna Sari Dewi as the buyer and DJM Sambara through his attorney named Matius Nika Tandipare as the attorney of DJM Sambara based on the Sale and Purchase Deed Number: 76 / AU / CA / VII / 1996 and 90 / AU / CA / VIII / 1996 dated July 26, 1996. First Freehold Certificate Number: 1507, area 4,024 m2 Situation Image (GS) dated 11 August 1988 Number: 1268/1988 in the name of Ratna Sari Dewi. And Certificate of Ownership Number: 1508, area 1,837 m2 Situation Image (GS) dated August 11, 1988 Number: 1267/1988 on behalf of Ratna Sari Dewi rather than the Sale and Purchase conducted by Ratna Sari Dewi with DJM Sambara. a land certificate issued earlier than a sale and purchase deed, not based on law and declared null and void, the issuance of the land certificate without any application being filed by the owner is invalid. However, taking into account the authority of the Court that has the right to cancel the certificate is the authority of the State Administrative Court (PTUN) and based on the Regulation of the Minister of Agrarian Number: 9 of 1999 Jo the Regulation of the Head of the National Land Agency Number: 3 of 2011 which regulates the authority of the National Land Agency land for which one of the elements is declared null and void by the BPN is juridical defects and physical defects which are administrative defects. For certificates that have administrative defects without a Court Decision BPN is authorized to issue a certificate cancellation decree.

\subsubsection{Aspects of Legal Certainty in Judgment and Decision of the Supreme Court Judges Number 1638K/ Pdt / 2010.}

Judges' decisions that reflect legal certainty certainly have a role in finding the right law in the process of resolving cases in a trial. Judges in making decisions are not only referring to the law, because the possibility of the law does not stipulate clearly, so the judge is required to be able to explore legal values such as customary law and unwritten law that lives in the community. The application of the law must be in accordance with the case, so that the judge is required to always be able to interpret the meaning of the laws and other regulations that form the basis of the decision. ${ }^{5}$ The application of the law must be in accordance with the case, so that the judge can construct the case being tried in its entirety, wise and objectively. Judges' decisions containing elements of legal certainty will contribute to the development of science in the field of law. This is because the decisions of judges who have legal power are no longer the opinions of the judges themselves but are opinions of the judiciary which will become a reference for the community.

Talking about certainty means talking about the necessity, the obligation, the certainty must, mandatory. More to talk about legal certainty, it should be the legal obligation, so as not to cause disputes.

According to Sudikno Mertukusumo that:

"Legal certainty is a guarantee that the law can be implemented well. Certainly, legal certainty has become an inseparable part, this is preferred for written legal norms. Because certainty itself is essentially the main goal

\footnotetext{
${ }^{1}$ Salim \& Erlies Septiana Nurbani, Penerapan Teori Hukum Pada Penelitian Disertasi dan Tesis (Buku Kedua), Ed.1, Cet.1, Rajawali Pers, Jakarta, 2014, halaman 31.

${ }^{2}$ Salim \& Erlies Septiana Nurbani, Ibid.

${ }^{3}$ Salim \& Erlies Septiana Nurbani, Ibid.

${ }^{4}$ Salim \& Erlies Septiana Nurbani, Ibid, halaman 31.

${ }^{5}$ Busyro Muqaddas, “Mengkritik Asas-asas Hukum Acara Perdata”, Jurnal Hukum Ius Quia lustum (Yogyakarta,2002)
} 
of the law. Legal certainty is the regularity of the community is closely related to certainty itself because the essence of order will cause a person to live with certainty in carrying out the activities required in carrying out the activities of community life itself. "1

Legal certainty is a guarantee that a law must be carried out in a good or proper way. Certainty is essentially one of the goals of the law. Legal certainty often leads to the flow of positivime because if the law does not have identity then it is no longer used as a guide or role model for everyone's behavior. ${ }^{2}$

Seeing the facts that the Judge's Consideration in the Supreme Court Decree Number 1638K / Pdt / 2010 is not in accordance with the principle of legal certainty because the land which was originally the land of Alm Munirah aka Amaq Dinah where the land was sold by his son namely Alm Musdah to DJM Sambara in 1983, which was sold by Alm Musdah only $800 \mathrm{~m} 2$ and at the time of the sale and purchase Alm Musdah received pressure and coercion from DJM Sambara who was a TNI Officer, his acquisition was not obtained in Good faith and in reality from the sale and purchase of the Certificate of Ownership was issued. (SHM) in 1994 with the Decree of the NTB Regional Office BPN on February 2, 1994 No. SK.520.1 / 737/1/790/62/94: SHM 507/1994 and No. SK.520.1 / 737/1/789/62/94: SHM 508/1994 and has been sold to Hj. Ratna Sari Dewi as the buyer and DJM Sambara through his attorney named Matius Nika Tandipare as the attorney of DJM Sambara based on the Sale and Purchase Deed Number: 76 / AU / CA / VII / 1996 and 90 / AU / CA / VIII / 1996 dated July 26, 1996. First Freehold Certificate Number: 1507, area 4,024 m2 Situation Image (GS) dated 11 August 1988 Number: 1268/1988 in the name of Ratna Sari Dewi. And Certificate of Ownership Number: 1508, area 1,837 m2 Situation Image (GS) dated August 11, 1988 Number: 1267/1988 on behalf of Ratna Sari Dewi rather than the Sale and Purchase conducted by Ratna Sari Dewi with DJM Sambara. a land certificate issued earlier than a sale and purchase deed, not based on law and declared null and void, the issuance of the land certificate without any application being filed by the owner is invalid. However, taking into account the authority of the Court that has the right to cancel the certificate is the authority of the State Administrative Court (PTUN) and based on the Regulation of the Minister of Agrarian Number: 9 of 1999 Jo the Regulation of the Head of the National Land Agency Number: 3 of 2011 which regulates the authority of the National Land Agency land for which one of the elements is declared null and void by the BPN is juridical defects and physical defects which are administrative defects. For certificates that have administrative defects without a Court Decision BPN is authorized to issue a certificate cancellation decree.

\section{Conclusion}

Based on the results of the research and discussion above, the author can draw the following conclusions:

\subsection{The Legal Position / Land Status of Disputed Objects in the Supreme Court Decision Number 1638K / Pdt / 2010 are as follows:}

The first is seen from the Benefit Aspect that Munirah Alias Amaq Dinah whose land has been confiscated and is now occupied by his heirs, Maemunah along with other residents, must obtain the greatest benefit and happiness for those residents who still occupy the land. So, the concept puts benefit as the main goal of law. Its size is as much happiness as possible for as many people as possible. Judging whether good or bad, just or not, this law is very dependent on whether the law is able to provide happiness to humans or not. Benefit is interpreted the same as happiness. Secondly, viewed from the aspect of ownership and protection that the judge's decision was not based on law, because the Certificate of Ownership No. 1507, area of 4,024 m2 in Situation (GS) was issued on 11 August 1988 Number: 1268/1988 on behalf of Ratna Sari Dewi and Ownership Certificate Number: 1508, area 1,837 m2 Situation Image (GS) dated August 11, 1988 Number: 1267/1988 in the name of Ratna Sari Dewi instead of buying and selling between Ratna Sari Dewi as the buyer and DJM Sambara through their attorney named Matius Nika Tandipare as the power of attorney DJM Sambara based on the Deed of Purchase Number: 76 / AU / CA / VII / 1996 and 90 / AU / CA / VIII / 1996 dated July 26, 1996. Therefore, the heirs of Amaq Dinah as the legal owner of the land are based on Garuda Pipil Number: 115 Persil Number: 9 of 1957 must be protected under applicable law.

\subsection{As for Judges' Considerations in the Decision of the Supreme Court Number 1638K / Pdt / 2010 Already Compliant / Not with Justice and Legal Certainty. \\ Judge's consideration in the Supreme Court's Decision Number 1638K / Pdt / 2010 is not in accordance with the principles of justice and legal certainty because the land belongs to Amaq Dinah based on Garuda Pipil Number: 115 Persil Number: 9 of 1957 which was seized by DJM and the acquisition of Ratna Sari Dewi not based on law, because due to the issuance of Certificate of Ownership Number: 1507, area of 4,024 m2 Situation Pictures (GS) dated August 11, 1988 Number: 1268/1988 on behalf of Ratna Sari Dewi and Certificate of Title Number: 1508,

\footnotetext{
${ }^{1}$ Sudikno Mertukusumo, Penemuan Hukum, Liberty, Yogyakarta, 2009, halaman 21. 24
} \\ ${ }^{2}$ Awaludin Marwan, Teori Hukum Kontemporer Suatu Pengantar Posmoderenisme Hukum, Rangkang Education, Yogyakarta, 2010, halaman}


area of 1,837 m2 Pictures Situation (GS) on 11 August 1988 Number: 1267/1988 on behalf of Ratna Sari Dewi instead of buying and selling between Ratna Sari Dewi as the buyer and DJM Sambara through his attorney named Matius Nika Tandipare as the attorney of DJM Sambara based on the Deed of Purchase Number: 76 / AU / CA / VII / 1996 and 90 / AU / CA / VIII / 1996 dated July 26, 1996. And the area listed in Garuda Pipil Number: 115 Persil Number: 9 of 1957 under the name of Amaq Dinah is all as 95000m2.

\section{References}

Book:

Achamd Ali, Perlindungan Hak Asasi Manusia Dibidang Kepemilikan Tanah, Komisi Nasional Hak Asasi Manusia, Jakarta, 2005.

Amiruddin \& Zainal Asikin, Pengantar Metode Penelitian Hukum, Ed. Revisi. Cet. 10, Rajawali Pers, Jakarta, 2018.

Anang Husni dan Itta Soraya, Antropologi Hukum, Cetakan Pertama, Mataram University Press, Mataram, 2018.

Arba, Hukum Tata Ruang dan Tata Guna Tanah (Prinsip-prinsip hukum perencanaan penataan ruang dan penatagunaan tanah), Pustaka Bangsa, Mataram, 2014.

Awaludin Marwan, Teori Hukum Kontemporer Suatu Pengantar Posmoderenisme Hukum, Rangkang Education, Yogyakarta, 2010.

Boedi Harsono, Hukum Agraria Indonesia Himpunan Peraturan-Peraturan Hukum Tanah, Cet. 19, Djambatan, Jakarta, 2008.

Salim \& Erlies Septiana Nurbani, Penerapan Teori Hukum Pada Penelitian Disertasi dan Tesis (Buku Kedua), Ed.1, Cet.1, Rajawali Pers, Jakarta, 2014.

Salim HS, Teknik Pembuatan Akta Pejabat Pembuat Akta Tanah, Rajawali Pers, Jakarta, 2016.

Sudikno Mertokusumo, Mengenal Hukum: Suatu Pengantar, Ed. Ke-3, Liberti, Yogyakarta, 1988. , Teori Hukum, Cetakan I, CV Mahakarya Pustaka, Yogyakarta, 2019.

Journal:

Busyro Muqaddas, "Mengkritik Asas-asas Hukum Acara Perdata”, Jurnal Hukum Ius Quia lustum (Yogyakarta, 2002)

Satjipto Rahardjo, Penyelenggaraan Keadilan Dalam Masyarakat Yang Sedang Berubah, Jurnal Masalah Hukum , 1993.

Sudikno Mertukusumo, Penemuan Hukum, Liberty, Yogyakarta, 2009. 